Przegląd Badań Edukacyjnych Educational Studies Review

ISSN 1895-4308

nr 26 (1/2018), s. 109-120

Roman Schulz ORCID: 0000-0002-7809-5754

e-mail: rosch@hot.pl

\title{
Lad edukacyjny jako (nieobecna) kategoria myśli pedagogicznej
}

http://dx.doi.org/10.12775/PBE.2018.006

\section{Educational Order as an (Absent) Category of Pedagogical Thought}

\section{Abstract}

The author of the article sees order as a category of the pedagogical thought, provides examples of the educational order and presents the parameters for educational order analysis.

Key words: philosophy of education, structuralism, cultural order, educational order.

\section{Punkt wyjścia}

W jednej ze swych wcześniejszych publikacji wyraziłem pogląd, że współczesna myśl pedagogiczna eksponuje (oraz dodatnio wartościuje) pewien wyselekcjonowany zbiór własności charakteryzujących społeczną instytucję wychowania. A mianowicie:

- to, co w niej partykularne, w odróżnieniu od tego, co uniwersalne;

- to, co w niej nowe (nieciągłe z tradycją), w odróżnieniu od tego, co stanowi kontynuację przeszłości;

- to, co pluralistyczne (wielorakie), w odróżnieniu od tego, co monistyczne (jednolite);

- to, co tymczasowe, zmienne, przejściowe, czy „sezonowe”, w odróżnieniu od tego, co trwałe, niepodlegające upływowi czasu; 
- to, co lokalne, w odróżnieniu od tego, co powszechne;

- to, co nieokreślone, płynne, amorficzne, w odróżnieniu od tego, co uporządkowane, ustrukturalizowane, zintegrowane;

- to, co progresywne, w odróżnieniu od tego co konserwatywne;

- to, co względne (relatywizm), w odróżnieniu od tego, co absolutne (fundamentalizm) (Schulz, 2016).

Powstaje w ten sposób - jak się zdaje - pewna nierównowaga, wyrażająca się w tym, że pewne ważne aspekty edukacji jako bytu socjokulturowego umykają uwadze pedagogów. Jako takie - znajdują się poza polem systematycznych obserwacji oraz dyskursu. Tymczasem każdy obraz świata (zawarty w konstrukcji mentalnej) - wydaje się bardziej trafny i przekonujący, gdy jednocześnie uwzględnia oraz objaśnia przeciwstawne aspekty istniejącej rzeczywistości; czyli to, że ludzie mogą być zarówno zdrowi, jak i chorzy, szczupli i otyli, pracowici i leniwi, cnotliwi i grzeszni.

Jeżeli w pojmowaniu zjawisk edukacyjnych dominantą staje się to, co w nich nieokreślone, zmienne, unikalne, różnorodne, wielorakie, partykularne, na plan drugi schodzą sprawy dotyczące integralności, stałości oraz tożsamości uniwersum edukacyjnego.

Jedną z takich „nieobecnych” kategorii światopoglądowych, która dotąd nie była poważnie brana pod uwagę w budowie intelektualnych wizji świata edukacyjnego, jest kategoria „ładu” i jego licznych pochodnych: struktury, organizacji, jedności itp. Pojęcie ładu odnosi się do aspektu zjawisk edukacyjnych nie mniej istotnego niż takie kategorie jak wartości, ideały, innowacje i reformy. Nie istnieją jakieś zasadnicze powody, dla których np. stabilność pedagogicznych ról, wzorów działań czy obyczajów nadawałaby się w mniejszym stopniu na materię pedagogicznej refleksji i badań niż zjawisko ich zmienności oraz rozwoju.

Spośród wielu powodów ignorowania strukturalnego wymiaru rzeczywistości pedagogicznej można w tym miejscu wymienić dwa: przekonanie o usługowości pedagogiki względem „,praktyki” oraz „normy poprawności” przyjmowane na terenie myśli pedagogicznej.

Jak wiadomo, klasyczna pedagogika koncentrowała uwagę przede wszystkim na substancjalnym oraz operacyjnym wymiarze zjawisk edukacyjnych. Takie aspekty rzeczywistości pedagogicznej, jak: cele wychowania, programy nauczania, podręczniki szkolne, kadra pedagogiczna, metodyka wychowania, wyniki nauczania, niepowodzenia dydaktyczne znajdowały się na pierwszym planie, a nawet stanowiły dominantę zainteresowań teoretyków wychowania. Strukturalny aspekt zjawisk edukacyjnych, jako trudniej poznawalny i manipulowalny, wydawał się, w perspektywie praktycznej, mniej istotny. 
Inną optyką, która stanowiła przeszkodę w strukturalnym oglądzie edukacji, a której stosowanie wymuszały normy poprawności w pedagogicznym myśleniu, była koncentracja na zmienności, dynamice, adaptacyjności oraz innowacyjności systemu edukacyjnego. Od pewnego czasu, głosami pedagogów teoretyków, edukacja nieustannie oznajmia, że chce (i musi) być czymś innym, niż jest. Do pewnego stopnia jest to zrozumiałe w zmieniającym się świecie. Orientacja taka nie pozwala jednak dostrzec w edukacji (oraz docenić) tego wszystkiego, co w niej sprawdzone, trwałe, uporządkowane; co stanowi podstawę jej statusu w zmieniającym się świecie oraz wśród innych bytów. R. Linton stwierdził kiedyś, że antropologów kulturowych w mniejszym stopniu interesuje wielość modeli rodzin w różnych kulturach; bardziej zaś to, że w większości społeczeństw, jeżeli nie we wszystkich, istnieje rodzina jako podstawowa forma organizacji społecznej.

Wymienione tu przykładowo czynniki (obok innych, np. „ducha czasów”) spowodowały łącznie, że w naukach o wychowaniu nie ukształtowała się jeszcze wizja zjawisk edukacyjnych uwzględniająca ,architekturę porządku edukacyjnego". Wynikiem tego jest zapewne zubożenie zasobów światopoglądowych pedagogiki oraz ograniczenie możliwości poznawczych tej dyscypliny.

Nie trzeba jednak żadnego wysiłku intelektualnego, by stwierdzić, że mimo zmian, które w niej zachodzą, dziedzina edukacji nie jest bynajmniej sferą zjawisk przebiegających w sposób losowy, przypadkowy czy chaotyczny. Z racji przynależności do kultury charakteryzuje ją swoisty ład i porządek, dzięki którym stosowanie wobec niej takich kategorii analizy kulturologicznej, jak: trwałość, jedność, tożsamość, funkcjonalność, integralność, ciągłość itp. wydaje się możliwe, uzasadnione i wskazane. Misją bezstronnej filozofii wychowania jest zaś nie tylko objaśnianie tego, że rzeczy się zmieniają, ale i tego, że trwają; że nie tylko są wielorakie, ale i jednolite; że społeczna instytucja wychowania stanowi wyodrębniony i trwały składnik systemu kulturowego, o wyrazistej tożsamości, wewnętrznie ustrukturalizowany, realizujący ważne funkcje względem społeczeństwa i poszczególnych jednostek.

Wypowiadając się na temat preferencji ideowych współczesnej myśli pedagogicznej, nie powinniśmy, oczywiście, tracić z pola widzenia istniejących już w pedagogice prób artykułowania, popularyzowania oraz stosowania perspektywy określanej jako „strukturalistyczna” lub „systemologiczna”. Przegląd polskiej literatury przedmiotu dowodzi obecności takich usiłowań w licznych tekstach z zakresu epistemologii pedagogiki (Krystyna Duraj-Nowakowa), organizacji pracy szkoły (Roman Schulz), systemu społecznego szkoły (Tadeusz Gołaszewski, Zbigniew Zaborowski), integralnego ujęcia procesu nauczania 
(Wincenty Okoń, Józef Półturzycki), funkcjonowania tzw. mikrosystemów wychowawczych (Aleksander Lewin, Julian Radziewicz), teorii zarządzaniu oświatą (Jerzy Tudrej) itp. Należy jednak podkreślić, że wszystkie te próby podejmowały zasadniczo problematykę mieszczącą się poza obszarem pedagogiki ogólnej, a w szczególności - poza tym działem filozofii wychowania, w którym następuje budowa światopoglądowych podstaw wychowania i pedagogiki. Na tym polu dążenie do budowy obrazu wychowania uwzględniającego jego parametry strukturalne pozostaje nadal zadaniem wymagającym podjęcia.

Jeżeli chodzi o sposób wprowadzania optyki strukturalistycznej do myśli pedagogicznej, to $\mathrm{w}$ grę wchodzi przede wszystkim przemyślana, unikająca powierzchowności, asymilacja dorobku tych licznych koncepcji naukowych i filozoficznych, które akcentują znaczenie kategorii „całości”, „organizacji” i „struktury” w poznawczym oglądzie rzeczywistości. Wymieńmy dla przykładu: psychologię gestalt, nurt funkcjonalistyczny w socjologii, teorię instytucjonalizmu socjologicznego, teorię organizacji i zarządzania, systemologię $\mathrm{i}$ inne.

\section{Pojęcie „ładu" - przegląd znaczeń}

Wiodąca dla tego tekstu kategoria „ładu” odnosi się do tych własności przedmiotów i zjawisk, które są współdesygnowane przez takie pojęcia, jak: „organizacja”, „struktura”, „porządek”, „,całość”, ,jedność”, „integracja” itp. Mimo pewnych różnic znaczeniowych istniejących między ww. kategoriami, mają one jednak wspólny komponent semantyczny, zasługujący tu na uwypuklenie.

Odnotujmy przede wszystkim niektóre synonimy wymienionych wyżej pojęć, zarejestrowane (w większej liczbie) przez witrynę https://synonim.net:

„Ład”: ustalony porządek, ustalone następstwo, harmonia, jedność, równowaga, układ, szyk, stabilność.

„Porządek”: architektura, kompleks, kompozycja, struktura, organizacja, organizm, system, ułożenie, uszeregowanie, formacja, ustrój, ład, zgodność, koordynacja, kolej rzeczy, kontinuum, sekwencja, pasmo, szereg, seria, trwanie, hierarchia, budowa, całość, konstrukcja, układ elementów, wzajemne powiązanie, anatomia.

„Struktura": architektura, całokształt, ciąg, kolejność, kompleks, kompozycja, konfiguracja, organizacja, organizm, porządek, rozkład, system, układ, uporządkowanie, ustawienie, architektonika, budowa, forma, konstrukcja, kształt, konstelacja, postać, anatomia, harmonia, całość, układ elementów, wzajemne powiązanie, grupa, zespół, ustrój, utwór. 
„Organizacja”: architektura, całokształt, ciąg, kolejność, kompleks, kompozycja, konfiguracja, organizm, porządek, rozkład, struktura, system, szyk, układ, ułożenie, uporządkowanie, sekwencja, uszeregowanie, architektonika, budowa, forma, konstrukcja, kształt, skład, uformowanie, konstelacja, postać, koordynacja, ustrój, instytucja, organ, urząd, chronologia, zgrupowanie, zjednoczenie, cykl, hierarchia, szereg, urządzenie.

„Całość”: całokształt, grupa, kompleks, konglomerat, skupisko, układ, zespół, ogół, suma, system, wszystko, pełnia, budowa, kompozycja, konstrukcja, porządek, rozkład, struktura, układ elementów, wzajemne powiązanie, jednolitość, jedność, spójność, wszyscy, zbiorowość.

„Integracja”: fuzja, koncentracja, konsolidacja, scalenie, połączenie, powiązanie, unifikacja, zespolenie, złączenie, kumulacja, skupianie, synteza, unia, zespalanie, związek, zharmonizowanie.

Stownik języka polskiego odnotowuje trzy podstawowe znaczenia „ładu”:

a) statyczne: „harmonijny układ czegoś; porządek”; np. „porządek w domu, w mieszkaniu";

b) dynamiczne: „następowanie po sobie według ustalonej kolejności; następstwo, układ kolejny czegoś; kolejność, ciąg, szyk”; np. „porządek obrad";

c) sprawcze: „robienie porządku; sprzątanie”; np. „wielkie, generalne, świąteczne porządki”.

Jako podstawa systematyzacji ww. znaczeń dobrze sprawdzi się następująca uwaga, którą sformułowałem w drugim tomie swych Wykładów z pedagogiki ogólnej: „,...organizacja, porządek, struktura, ład rzeczywistości to podstawowe własności, uwypuklane w systemowym oglądzie świata. [...] W większości definicji ujmuje się swoistość tworów systemowych w terminach takich opozycji jak: »część - całość«, »skład - organizacja«, »zbiór - system «, »analiza - synteza«, »atomizm - holizm«, »zmienność - stałość«, »wielość - jedność«, »szczegół - ogół«, »chaos - porządek«, »substancja - struktura«". Opozycje te dają pośrednio wyobrażenie o tym, w ilu i jakich znaczeniach powinna być interpretowana wiodąca dla niniejszego studium kategoria „ładu” (Schulz, 2007, s. 40).

Oto proponowana lista sensów (enumeratywna, bez zwyczajowego podziału na znaczenia potoczne, wartościujące, sprawozdawcze, naukowe itp.):

- ład jako synonim „harmonijnego układu czegoś”; przeciwieństwo nieporządku, dezorganizacji, bałaganu; opozycja: „chaos - porządek”;

- ład jako synonim porządku „pożądanego lub” „idealnego”, w przeciwieństwie do porządku ,realnego", „faktycznie istniejącego”; opozycja: „ład realny - ład idealny”; 
- ład jako synonim stałości, trwałości, przeciwieństwo zmienności; opozycja „stałość - zmienność”;

- ład jako synonim jedności; przeciwieństwo wielości, rozmaitości; opozycja „mnogość - jedność”;

- ład jako synonim całości, zespolenia; przeciwieństwo agregacji, zbioru, zatomizowanych części; opozycja „,część - całość”; „ogół - szczegół”;

- ład jako synonim organizacji, struktury; przeciwieństwo składu, substancji, treści; opozycja „skład - organizacja”, „substancja - struktura”;

- ład jako synonim systemu; przeciwieństwo układu addytywnego; opozycja „zbiór - system”.

Wydaje się, że wszystkie wyróżnione wyżej znaczenia mają zastosowanie w określaniu i opisie porządku jako jednego z wymiarów edukacji.

\section{tad edukacyjny - zarys idei}

W sensie elementarnym, a zatem podstawowym, każdy ład jest przeciwieństwem chaosu, bezładu, improwizacji, braku organizacji. Istnienie ładu edukacyjnego sprowadza się generalnie do tego, że sprawy związane ze świadczeniem usług opiekuńczych oraz międzypokoleniowym przekazem kultury w zbiorowościach ludzkich nie zostały zawierzone przypadkowi, nie przebiegają losowo, lecz są w jakiś sposób regulowane, normowane, strukturalizowane; że jest im właściwa pewna organizacja; że przebiegają wedle jakiegoś porządku, w sposób ujednolicony, unormowany, stosownie do ładu właściwego nadsystemowi społecznemu. Ład ten jest zasadniczo ładem kulturowym z racji statusu edukacji jako składowej części kultury.

Przejawy ładu można stwierdzić we wszystkich dziedzinach społecznej instytucji wychowania jako bytu kulturowego, a mianowicie: w sferze materialnych podstaw edukacji, w edukacyjnej socjosferze, w systemie semiotycznym edukacji oraz w formach świadomości edukacyjnej społeczeństwa.

Ład w sferze kultury materialnej (rzeczowo pojmowanej) przejawia się np. w architekturze i zasadach konstrukcji budynków szkolnych, w układzie sieci szkolnej, w strukturalizacji przestrzeni domowej, w organizacji materialnego środowiska domu rodzinnego („kącik domowy” dla dziecka), w stroju i wyposażeniu ucznia (dawniej - „niebieski mundurek”), w wykorzystywaniu rozmaitych narzędzi wpływu edukacyjnego (tablica szkolna, zeszyt, pióro, długopis) i wielu innych zjawiskach. Wymienione urządzenia, obiekty i narzędzia to ewidentne składowe materialne ładu edukacyjnego, elementy materialnej kultury wychowania. 
Jeżeli chodzi o ład charakteryzujący edukacyjną socjosferę, to można go uważać za szczególną postać, szczególny przypadek ładu społecznego w ogóle. Jego wyrazem jest zjawisko uporządkowania, strukturalizacji, organizacji interakcji międzyludzkich w ich ważnym aspekcie, jakim jest kształtowanie i rozwój dorastających pokoleń (ogólniej - osób uczących się lub podlegających rozwojowi).

Międzyludzki (,społeczny”) wymiar ładu edukacyjnego najwygodniej jest opisywać za pomocą dwóch kategorii, które dowiodły już swej skuteczności w innych naukach, a mianowicie „morfologii” tworów społecznych (będących nośnikami strukturalnymi dla realizacji funkcji rozwojowych) oraz „fizjologii” ich funkcjonowania. W przypadku optyki „morfologicznej” w centrum uwagi znajduje się ład edukacyjny (społeczny), w jego aspekcie statycznym, biernym, a w jego charakterystyce wykorzystuje się takie pojęcia desygnujące formy organizacji społecznej, jak: „pozycja”, „rola”, „grupa”, „struktura”, „,organizacja”, „,układ”, „system”, ustrój” czy (rekomendowany przez autora) „,integron edukacyjny”.

W tym segmencie życia zbiorowego, w którym „ludzie kształtują ludzi”, a należy do nich edusfera, porządek społeczny wyraża się w powstawaniu, funkcjonowaniu i trwaniu określonych, a zarazem specyficznych układów, struktur czy form organizacji społecznej. Są to twory systemowe, stanowiące podstawę strukturalną dla realizacji funkcji edukacyjnych w społeczeństwie.

Osobliwość tych układów polega na tym, że są one zintegrowaniem, zespoleniem dwóch kategorii pozycji i ról: a) pozycji i ról związanych z „kształtowaniem ludzi”, tj. z wywieraniem wpływu edukacyjnego, oraz b) pozycji i ról związanych z podleganiem wpływowi edukacyjnemu. Nie jest trudno o przykłady takich jednostek strukturalnych w edusferze: rodzina (w swej funkcji opiekuńczo-wychowawczej), przedszkole, uczelnia wyższa, dom dziecka, zakład resocjalizacyjny, ustrój szkolny, system oświatowy itp.

Natomiast w przypadku optyki „fizjologicznej” chodzi o ład edukacyjny w jego aspekcie czynnym, operacyjnym, odnoszący się do procesów transformacyjnych, zachodzących $\mathrm{w}$ integronach edukacyjnych. Ład ten jest konceptualnie wyrażany z zastosowaniem takich pojęć, jak: czyny, działania (np. „lekcja”), wzory zachowań interpersonalnych (np. „korepetycje”), konfiguracje działań (np. „kurs wykładowy na uczelni”), cykle zdarzeń (np. „rok szkolny”), nawyki (np. „kontrola obecności na zajęciach”), obyczaje (np. „organizacja uroczystości szkolnych”), instytucje (np. ,egzamin maturalny”), sformalizowane systemy działania (np. „kurs na prawo jazdy”) itp. Problemem naczelnym w tej perspektywie jest organizacja, strukturalizacja procesów transformacyjnych, zachodzących w obrębie integronów edukacyjnych. 
W zależności od skali i charakteru zjawisk, których dotyczy, ład procesualny w edukacyjnej socjosferze przybiera trojaką postać: ładu telicznego (celowościowego), odnoszącego się zasadniczo do zindywidualizowanych relacji edukacyjnych; ładu instytucjonalnego, typowego dla interakcji międzygrupowych, oraz ładu systemowego, właściwego interakcjom z poziomu intergeneracyjnego.

Trzecim, po kulturze materialnej i socjosferze, segmentem edusfery, w którym stwierdza się występowanie elementów ładu, jest sfera języka oraz komunikacji symbolicznej. Język to - jak wiadomo - system konwencjonalnych znaków dźwiękowych (mowa) oraz pisanych (pismo) służących do porozumiewania się ludzi między sobą, do przekazywania informacji, a ponadto do: zapisu i utrwalania gromadzonych doświadczeń, tj. wyników uczenia się i poznania, do wyrażania stanów wewnętrznych podmiotu, do sterowania działaniem, do modelowania zachowań.

Kategorie (słowa kluczowe) służące do opisu tej szczególnej formy behawioru ludzkiego są, jak wiadomo, następujące: zachowania werbalne, mowa, pismo, dyskurs, znak, znaczenie, komunikat, semioza, lingwistyka itp.

W dziedzinie edukacji, podobnie jak w innych segmentach kultury, język i komunikacja symboliczna ukształtowały się i rozwinęły dla realizacji ściśle określonych funkcji, związanych z nabywaniem, przetwarzaniem, komunikowaniem oraz stosowaniem wyuczonej informacji. Jako takie, systemy semiotyczne edukacji umożliwiają sprawniejsze:

- odwzorowywanie i zapis inwariantów rzeczywistości edukacyjnej (rejestrowanych za sprawą pedagogicznego uczenia się i poznania) w kodach symbolicznych (np. słowach, twierdzeniach, liczbach), w odróżnieniu np. od kodu behawioralnego (np. wzorach zachowań);

- ekspresję - w formie symbolicznej - stanów duchowych (przeżyć, wartości, oczekiwań) podmiotów ładu edukacyjnego (indywidualnych lub zbiorowych);

- utrwalanie oraz archiwizację - w mowie lub piśmie - wyników uczenia się oraz poznania;

- komunikowanie (obieg) symbolicznie zakodowanej informacji w systemie edukacyjnym oraz w społeczeństwie;

- realizowanie operacji kierowania (regulowania) funkcjonowaniem pedagogicznych instytucji.

System semiotyczny edusfery jest dość rozbudowany. Można wyróżnić w nim trzy podstawowe kategorie stosowanych ,języków”: 
a) języki wychowującego społeczeństwa, np. język potoczny (prywatny lub publiczny), język instytucji oświecenia publicznego; język organizacji politycznej społeczeństwa, język prawa, język sztuki etc.

b) języki formalnego systemu edukacyjnego, np. profesjonalny język nauczycielski, żargon uczniowski, urzędowy język administracji oświatowej etc.

c) języki pedagogiki, np. język pedagogów teoretyków, język pedagogiki empirycznej, język filozofów wychowania, język nauk współpracujących z pedagogiką etc.

Wydaje się, że cecha uporządkowania edukacyjnej semiozy może odnosić się do następujących aspektów i wyrażać się w: a) ustalonym i uprofilowanym zasobie słownictwa (systemu pojęciowego); b) ustalonych znaczeniach poszczególnych pojęć; c) regułach rządzących gramatyką wypowiedzi; d) frazeologii i stosowanych konwencjach językowych, oraz e) sposobach komunikowania się. Ład semiotyczny edukacji to ciekawy temat eksploracji dla młodych pedagogów.

Czwarty segment edusfery, w którym można doszukiwać się elementów ładu, to formy świadomości edukacyjnej społeczeństwa, określane także mianem kultury duchowej edukacji. Formy świadomości to wszystkie sposoby symbolicznego odzwierciedlania, przedstawiania sobie przez człowieka swego środowiska naturalnego i społecznego, samego siebie, a także swego położenia w świecie. Ta wieloraka działalność „odwzorowująca” przybiera takie formy, jak: mitologia, wierzenia religijne, myśl potoczna, opinia publiczna, sztuka, literatura, różne formy ideologii społecznej, nauka, filozofia itp.

Będąc rozwiniętym segmentem życia zbiorowego, także dziedzina edukacji dopracowała się swoich form świadomości, swojej kultury duchowej. Po bliższą ich charakterystykę odsyłam do jednej ze swych wcześniejszych publikacji ${ }^{1}$. W tym miejscu warto wyeksponować różnicę między przedteoretycznymi oraz teoretycznymi formami świadomości edukacyjnej. Do pierwszych należą: myśl i wyobrażenia potoczne, edukacyjna opinia publiczna, dyskurs literacko-artystyczny, pedagogiczna opinia publiczna etc. Natomiast teoretyczne formy świadomości to zaawansowana część kultury duchowej edusfery, która obejmuje tylko intelektualne, umysłowe, poddane racjonalizacji, mające postać systemu obrazy świata, będące efektem pracy zdyscyplinowanego umysłu. Konstrukcje te są na ogół wyrażane w takich „złożonych wypowiedziach”, jak:

1 Wykłady z pedagogiki ogólnej, tom III, Logos edukacji, Wydawnictwo Naukowe UMK, Toruń 2009 (rozdz. X. Formy świadomości edukacyjnej). 
ideologie pedagogiczne, doktryny pedagogiczne, koncepcje filozoficzne, teorie pedagogiczne, teorie naukowe itp. W tym przypadku mamy zatem do czynienia $\mathrm{z}$ aktywnością, którą należy określać raczej jako kultura umysłowa niż duchowa.

Jeżeli dawać wiarę temu, „co ludzie mówią” (a mówią: „co pedagog to inna wizja edukacji i pedagogiki"), to prezentowana obecnie dziedzina edusfery poczyniła najmniejsze postępy na drodze do zaprowadzenia u siebie ładu i porządku. Nie powinno to jednak nikogo dziwić. Kultura duchowa edukacji ukształtowała się bowiem w odpowiedzi na stojące przed edusferą wyzwania adaptacji do wymogów zmiennego otoczenia i z natury rzeczy pozostaje w swej naturze, procedurach oraz wytworach bardziej wieloraka, różnorodna, płynna i zmienna niż poprzednio wyszczególnione obszary ładu.

Istotnie - kultura duchowa edukacji to obszar nieustannej twórczości ideowej i poznawczej, teren pluralizmu oraz różnorodności idei, poglądów i prawd, scena szybkich narodzin, dyfuzji oraz dezaktualizacji lub zaniku wielu różnych obrazów świata edukacyjnego. Jako taka wydaje się zupełnym przeciwieństwem tego, co ustalone, uporządkowane, zorganizowane, trwałe.

Niemniej także w omawianej obecnie dziedzinie, choć w znacznie skromniejszym zakresie, stwierdza się występowanie mechanizmów integracyjnych, dążenie do strukturalizacji tego, co amorficzne, ujednolicania tego, co wielorakie, porządkowania tego, co różnorodne, algorytmizowania tego, co spontaniczne. Klasycznym przejawem występowania w myśli pedagogicznej tendencji scalającej i porządkującej jest ograniczanie wielości i rozmaitości jej wytworów (głównie tzw. koncepcji wychowania) poprzez ich kategoryzowanie w określone „prądy ideowe”, „kierunki myśli” czy „doktryny pedagogiczne”. W pedagogice prakseologicznej, będącej w początkach swego istnienia swoistym „teatrem rozmaitości”, nastąpiło ukonstytuowanie się określonych „subdyscyplin pedagogicznych", specjalizujących się w monitorowaniu, zapisie doświadczeń oraz modelowaniu wybranych segmentów praktyki pedagogicznej. Na płaszczyźnie kształcenia akademickiego odpowiada temu istnienie określonych „kierunków kształcenia”, „specjalizacji” oraz „przedmiotów studiów”. Wreszcie tzw. pedagogika scjentystyczna, korzystając z dorobku innych nauk (oraz własnego), dopracowuje się mozolnie swojej metodologii, zmierzającej do ,zalgorytmizowania” procedury badawczej w pedagogice przez poddanie jej pod kontrolę ściśle określonych reguł, a także dokonanie standaryzacji wytworów poznania naukowego - bez uszczerbku dla ich walorów inwencyjnych oraz odkrywczych. 


\section{Lad edukacyjny: wybrane parametry analizy}

W podsumowaniu warto sporządzić listę niektórych parametrów, możliwych do zastosowania w bardziej szczegółowej charakterystyce ładu edukacyjnego.

- Ład jako konstytutywna vs. drugorzędna własność edusfery.

- Miejsce i funkcje ładu edukacyjnego w ogólnym porządku socjokulturowym.

- Tworzywo (materia, substancja) ładu edukacyjnego.

- Złożoność (hierarchia) ładu edukacyjnego.

- Monizm vs pluralizm ładu edukacyjnego. Zagadnienie ładu deterministycznego, celowościowego, instytucjonalnego oraz systemowego.

- Geneza ładu. Jak wyłania się porządek z chaosu w dziedzinie edukacji? Jakie sytuacje i potrzeby leżą u podstaw jego narodzin i rozwoju? Co stanowi rację jego istnienia? Kształtowanie się ładu jako proces przystosowawczy.

- Informacyjne podstawy ładu edukacyjnego.

- Trwałość, stabilność porządku edukacyjnego? Jakie czynniki decydują o jego egzystencji w czasie, utrzymywaniu swej struktury, samoodtwarzaniu się, mimo wymiany elementów składowych oraz zmienności warunków środowiskowych?

- Rozwój ładu edukacyjnego: istota rozwoju (różnica między zmianą w systemie a zmianą systemu), czynniki napędowe, mechanizm, kierunki, kryteria postępu.

- Stany normalne i zaburzone (patologiczne) w sferze ładu edukacyjnego.

Dla młodych pedagogów, aspirujących do podboju „ziem nieznanych”, problematyka strukturalnych podstaw edukacji może stanowić interesujący obszar studiów, badań oraz praktycznych interwencji.

\section{Bibliografia}

Duraj-Nowakowa, K. (1992). Teoria systemów a pedagogika. Kraków: WSP.

Duraj-Nowakowa, K. (1996). Procedura modelowania systemowego dydaktyki. Kraków: WSP.

Lewin, A. (1983). System wychowania a twórczość pedagogiczna. Warszawa: Wydawnictwo Naukowe PWN.

Gołaszewski, T. (1977). Szkoła jako system społeczny. Warszawa: Wydawnictwo Naukowe PWN. 
METAANALIZY BADAŃ EDUKACYJNYCH

Schulz, R. (1993). Szkoła jako organizacja. Toruń: Wydawnictwo Uniwersytetu Mikołaja Kopernika.

Schulz, R. (2007). Wykłady z pedagogiki ogólnej, t. 2. Toruń: Wydawnictwo Naukowe Uniwersytetu Mikołaja Kopernika.

Schulz, R. (2016). Szkice z pedagogiki ogólnej. Toruń: Wydawnictwo Adam Marszałek. 